\title{
ZNACZENIE POJECCIA INTYMNOŚCI I PRAWA DO JEJ POSZANOWANIA W ŚWIETLE DOŚWIADCZEŃ RODZĄCYCH KOBIET
}

\begin{abstract}
Abstrakt. Przedmiotem zainteresowania w niniejszym artykule jest intymność w warunkach porodu - jak jest ona odczuwana przez rodzące, co decyduje o tym, że narodziny dziecka są dla nich intymnym wydarzeniem, co jest naruszeniem ich intymności. Zrealizowano badanie jakościowe, oparte na analizie opowieści porodowych, zebranych i upublicznionych przez Fundację Rodzić po Ludzku. Punktem wyjścia dla analizy były ustalenia, jak w języku polskim rozumiane jest pojęcie intymności, jakie ma ona znaczenie w procesach interakcji społecznych i komunikacji, z odczuwaniem jakich emocji wiąże się jej naruszenie, a także jak określa się ją i chroni w polskim prawodawstwie, w tym w przepisach określających prawa pacjenta. Przybliżono także wyniki badań realizacji prawa do intymności, poszanowania godności i podmiotowości w polskich placówkach położniczych. Analizując narracje kobiet, w których dzieliły się one swoimi przeżyciami i refleksjami dotyczącymi porodów, a także pobytów w szpitalu w związku z poronieniem, przyjęto, że wskaźnikiem naruszenia/poszanowania ich intymności są ich odczucia, wyrażane w opowieściach emocje, sposób opowiadania o doświadczeniu. Analiza porodowych opowieści pozwoliła na ustalenie, że intymność w czasie porodu wiąże się z poczuciem kontroli kobiety nad dostępem innych do jej ciała, jej wiedzą i zgodą dotyczącą czynności i medycznych interwencji, ingerujących w jej cielesność i przebieg porodu. Kluczowe jest także poszanowanie emocji, potrzeb, oczekiwań rodzącej przez personel medyczny, traktowanie jej z szacunkiem, jako osoby, podmiotu, pierwszoplanowej postaci w procesie porodu. Uwzględnianie i ochrona granic intymności jednostki wiąże się z uznaniem jej autonomii i sprawstwa oraz poszanowaniem jej osobistej godności.
\end{abstract}

Slowa kluczowe: poród, opowieści porodowe, intymność, godność, autonomia, podmiotowość, wstyd.

* Dr, Katedra Socjologii Struktur i Zmian Społecznych, Instytut Socjologii, Wydział Ekonomiczno-Socjologiczny, Uniwersytet Łódzki, ul. Rewolucji 1905 r. 41/43, 90-214 Łódź, e-mail: krystyna.dzwonkowska@uni.lodz.pl 


\section{Wstęp}

Celem niniejszego artykułu jest analiza sposobu rozumienia, a właściwie odczuwania intymności przez rodzące kobiety. Materiał badawczy stanowiły opowieści porodowe, zebrane i udostępnione przez Fundację Rodzić po Ludzku na stronie internetowej organizacji. W pierwszej części artykułu przybliżono, w jakich znaczeniach i kontekstach używa się pojęć ,intymność” i ,intymny” w języku polskim, następnie wskazano, jak funkcjonują one w procesach interakcji i komunikacji międzyludzkiej. Omówiono powiązanie intymności z emocją wstydu, wywoływaną m.in. nagością, przekroczeniem przez innych granic wyznaczanych przez jednostkę i służących ochronie własnego ,ja”, własnej godności, podmiotowości, cielesności. Wreszcie kontekst dla analizy znaczenia pojęcia intymności i prawa do jej poszanowania w relacjach rodzących stanowi także sposób ujmowania intymności w systemie aksjonormatywnym - w przepisach prawnych, w tym prawach pacjenta, oraz praktyki (nie)przestrzegania prawa do intymności w polskich szpitalach położniczych. W analizie opowieści porodowych skupiono się na doświadczeniach kobiet, odnoszących się do poszanowania i naruszania intymności w warunkach porodu.

\section{Pojęcie intymności}

Zacznijmy od słownikowych znaczeń słów „intymność” i „,intymny”, przybliżających ich rozumienie i zastosowanie w języku polskim. Bieńko w swojej książce poświęconej intymnym praktykom codzienności przypomina, że terminy te pochodzą od łacińskiego słowa ,intimus”, oznaczającego w dosłownym tłumaczeniu coś „najbardziej wewnętrznego, ściśle osobistego, wewnętrznie głębokiego, sekretnego, tajnego" (Bieńko 2013: 17). W trzytomowym Stowniku języka polskiego wydanym przez PWN podano następujące znaczenia przymiotnika ,intymny”: przeznaczony dla najbliższych, ściśle osobisty, poufny, sekretny, zażyły, wraz z przykładami: Intymne rozmowy, zwierzenia. Najintymniejsze myśli (Szymczak 1988: 805). Wskazano, że rzeczownik ,intymność” pochodzi od przymiotnika ,intymny”, podając przykład zastosowania: Nastrój intymności (Szymczak 1988: 805). Z kolei w Stowniku współczesnego języka polskiego „intymność” zdefiniowano jako „sferę ściśle osobistych spraw człowieka, związanych wyłącznie z daną osobą i jej najbliższymi” (Dunaj 1996: 328). Pokazano użycie tego słowa w następującym kontekście: Mieć prawo do intymności. Pogwałcić, naruszyć czyjąś intymność. Intymność listów, zwierzeń. Potrzeba intymności (Dunaj 1996: 328). Zastosowanie przymiotnika „intymny”, rozumianego jako „dotyczący czyichś ściśle osobistych spraw, niedostępny dla osób postronnych, obcych; poufny, zażyły, ściśle prywatny", zilustrowano takimi przykładami: Intymne słowa, rozmowy, wyznania. Higiena intymna. Szukać intymnego miejsca (Dunaj 1996: 328-329). 
W Wielkim stowniku frazeologicznym języka polskiego (Müldner-Nieckowski 2003) przy wyrazie ,intymny” pojawia się odniesienie do dwóch innych wyrazów: „sfera” oraz „życie”. W pierwszym przypadku „sfera intymna” jest definiowana jako „to, co dotyczy prywatności, co może być wstydliwe”, i pojawia się przykład następującego zastosowania tego określenia: „Kiedy pytaniami wkraczasz w sferę intymną pacjenta, powinieneś być szczególnie delikatny i ostrożny” (Müldner-Nieckowski 2003: 700). W drugim przypadku - „życia intymnego" - mamy wyjaśnienie, że chodzi o ,prywatną, osobistą sferę życia; też: życie płciowe".

Przytoczone definicje i przykłady pokazują, że pojęcie intymności z jednej strony odnoszone jest do jednostki - jako indywiduum, osoby mającej sobie tylko właściwy zasób i zakres przeżyć, myśli, emocji, którymi może, ale nie musi się dzielić z innymi. W takim ujęciu eksponuje się subiektywność, niepowtarzalność, wyjątkowość intymności jako indywidualnego doświadczenia; postrzeganie, odczuwanie, przeżywanie jej w specyficzny sposób przez każdego człowieka, wyznaczającego jej granice i wymiary. $Z$ drugiej strony, pojęcie intymności stosowane jest do opisu relacji między jednostkami - bardzo bliskich, opartych na dużej zażyłości i emocjonalnym zaangażowaniu, na bliskim kontakcie fizycznym, także o charakterze seksualnym. W obu przypadkach intymność wiązana jest z prywatnością, czyli tym, co mieści się w przestrzeni życia prywatnego (nie-publicznego, nie-upublicznianego), związanej z emocjami, bliskością, cielesnością, seksualnością. Społeczny wymiar podziału na sferę prywatną i publiczną przejawia się w tym, jak w danej kulturze rozumiana jest prywatność (sfera prywatna) i intymność - co jest traktowane jako intymne, prywatne, jakie są tego granice, jakie znaczenie się temu przypisuje, czy i jakiej ochronie to podlega. Społeczne wyobrażenia i społeczne praktyki intymności, jak zauważa Sut, „mogą warunkować, w taki czy inny sposób, intymności indywidualne, które z kolei, o ile są widoczne, ujawniane lub upubliczniane, mogą wpływać na ową społeczną praktykę i wyobrażenia" (Sut 2019: 33-34).

\section{Intymność w perspektywie socjologii interakcji i komunikacji oraz socjologii emocji}

Jak wynika z przytoczonych wcześniej słownikowych definicji słów ,intymność” i „,intymny”, odnoszą się one do relacji międzyludzkich - interakcji między jednostkami oraz komunikacji. Dotyczą spraw, aspektów życia, którymi jednostka może dzielić się z innymi, ale może też je przed nimi skrywać, pozostawiać nieujawnione. Stosowanie przymiotnika ,intymny” do określenia zwierzeń, rozmów czy listów wskazuje, że człowiek może zaprosić do świata swoich wewnętrznych przeżyć drugą osobę, może je komunikować. $Z$ drugiej strony, sformułowania mówiące o „wkraczaniu w intymne sprawy człowieka” 
świadczą o istnieniu granic stawianych przez jednostkę, wyznaczających zakres tematów, o których może ona $\mathrm{i}$ chce $\mathrm{z}$ innymi rozmawiać, a których to granic nie powinni oni naruszać, przekraczać bez jej przyzwolenia. Przy czym granice te mają nie tylko charakter indywidualny, ale także społeczny, przyjmując formę uznawanych w danej kulturze konwencji, wzorów komunikacji i zachowania, wyznaczających porządek interakcyjny i interakcyjne rytuały (Goffman 2006a; Goffman 2006b). Dotyczy to także intymności w komunikacji niewerbalnej. Jak zauważa Goffman, interakcje międzyludzkie, szczególnie te bezpośrednie, twarzą w twarz, oparte na cielesnej współobecności, zawsze wiążą się z ryzykiem zagrożenia osobistego terytorium, przejawiającego się zarówno w naruszeniu integralności cielesnej, jak i psychiczno-emocjonalnej jednostki (Goffman 2006a: 295). W komunikacji niewerbalnej ochronie przed niepożądanym kontaktem fizycznym, wyznaczaniu granic cielesnej bliskości służy wyodrębnienie - zarówno na poziomie indywidualnym, jak i społecznym - sfer przestrzeni wokół jednostki i zasad określających, kto i w jakim celu może w poszczególnych sferach przebywać. Hall wskazuje na cztery dystanse utrzymywane przez człowieka: intymny, indywidualny - osobniczy (określany przez innych autorów także jako prywatny), społeczny i publiczny (Hall 1978: 156-174; por. też Giddens 2004: 117). Z racji podjętego tematu przybliżymy tylko ten pierwszy. Dystans intymny, wynoszący do pół metra, pozwala na porozumiewanie się szeptem, wiąże się z fizyczną bliskością drugiej osoby, związaną z dotykiem i sensorycznymi doznaniami, która, gdy jest niechciana, może być przytłaczająca. Ta strefa przestrzeni zarezerwowana jest dla szczególnych kontaktów społecznych - z osobami bardzo bliskimi, pozostającymi w relacjach dopuszczających częsty kontakt fizyczny (rodzice - dzieci, kochankowie) (Giddens 2004: 117). Do sfery tej jednostka dopuszcza także obce osoby, wykonujące zawód lekarza, pielęgniarki, masażysty, fryzjera czy kosmetyczki, których praca wymaga bliskiej fizycznej obecności i fizycznego kontaktu.

Wkroczenie w intymną sferę drugiego człowieka z pogwałceniem jej granic, czy to w komunikacji werbalnej, czy w kontakcie fizycznym, wywołuje u jednostki negatywne emocje. $Z$ reguły jest to wstyd, traktowany jako jedna z pierwotnych, podstawowych i społecznych emocji (por. Konecki 2014: 16). Odwołujemy się tu do koncepcji wstydu Scheffa, odnoszącego to pojęcie do szerokiej gamy emocji związanych z negatywnym postrzeganiem siebie ze względu na przekonanie jednostki o jej niekorzystnym społecznym wizerunku (Scheff 2011: 254). W niniejszym opracowaniu, poświęconym intymności i poczuciu jej naruszania w warunkach porodu, odnosimy się do tego wymiaru wstydu, który przejawia się w uczuciach zażenowania, onieśmielenia, zakłopotania, skrępowania, przykrości (nie w poczuciu winy, spowodowanym świadomością niewłaściwego zachowania, złamania społecznych norm) (Chajbos 2019: 67; Danieluk 2006: 75-76). Wstyd jest postrzegany i przeżywany jako emocja negatywna, wpływająca na pogorszenie samooceny. Bowiem, jak zauważają Czub i Brzezińska, 
w efekcie doświadczania wstydu zmienia się [...] sposób odczuwania siebie. Taki stan opisywany jest przez ludzi jako utrata szacunku do siebie, zachwianie poczucia własnej wartości, odczucie zdegradowania, pomniejszenia albo poniżenia. Do doświadczenia wstydu należy również chęć ukrycia się, zniknięcia lub „zapadnięcia się pod ziemię” (Czub, Brzezińska 2013: 2).

Wstyd jest przeciwieństwem dumy i, jak wskazywał Cooley w swojej koncepcji jaźni odzwierciedlonej, jest jedną z reakcji na wyobrażenia jednostki, jak jest ona widziana i oceniana przez innych (za: Scheff 2011: 242; por. także Konecki 2014: 16).

W kontekście podjętej problematyki - intymności w warunkach porodu - istotne jest zwrócenie uwagi na odczuwanie wstydu w związku z własną cielesnością i fizjologią. Wstydliwość związana z tymi sferami funkcjonowania człowieka jest efektem socjalizacji i kontroli społecznej nad ciałem. Jak pisał Elias, uspołecznienie jednostki obejmuje ,ucywilizowanie ciała” (za: Jakubowska 2009: 233), jego zdyscyplinowanie i ujarzmienie (Jakubowska 2009: 233 i nast.). Wymaga to przyswojenia zasad regulujących, jak ciało ma wyglądać, co z cielesności można pokazać, odkryć publicznie, jak mają być zaspokajane potrzeby fizjologiczne. Internalizując te reguły, człowiek, kierowany wewnętrznym przymusem, nie pozwala sobie na niestosowne - społecznie nieakceptowane zachowania, rozumie, co jest dopuszczalne w publicznej przestrzeni, w obecności innych, ma poczucie bycia obserwowanym i ocenianym.

Wstyd pełni także funkcję ochronną wobec cielesności i prywatności człowieka (Rzepa i in. 2013: 54). Odczuwanie go jest sygnałem, że naruszone zostały granice wyznaczające intymną sferę jednostki, że wkroczyła w nią inna, nieproszona, niechciana osoba. Uczucie to może się pojawić także w sytuacji, w której człowiek przyzwala na przekroczenie intymnego dystansu innemu, np. $\mathrm{w}$ relacji lekarz/pielęgniarka - pacjent. W przypadku leczniczych czy pielęgnacyjnych zabiegów mamy do czynienia z przymusową nagością (Polińska 2020: 8). Banaszak określa ją mianem nagości przez małe „n” - „roboczo-praktycznej, instrumentalnej, wynikającej z życiowych konieczności: operacja, poród, wizyta u lekarza, karmienie dziecka, ale też podczas przebierania się czy korzystania z łazienki” (Banaszak 2017: 196). To, „czy pacjent będzie się czuł obnażony, goły, odarty ze swojej intymności", zależy w dużej mierze od tego, jaka jest ta relacja, co z kolei warunkowane jest m.in. postawą osoby wykonującej zawód medyczny (Polińska 2020: 288). Znaczenie ma tu także subiektywny stosunek jednostki do własnej nagości (Polińska 2020: 8). Ludzie różnią się wrażliwością na odsłonięcie ciała, zakresem akceptacji i chęci odkrywania różnych jego części, reakcjami na sytuacje wymagające ich nagości. Z drugiej jednak strony, muszą

${ }^{1}$ Nagość przez duże „n” autorka wiąże z intymnością bliskich relacji, byciem nagim z wyboru, wolnym z reguły od uczucia wstydu, w nacechowanym emocjami, intymnym fizycznym kontakcie z drugą osobą (Banaszak 2017: 202). 
liczyć się z przyjętymi w danym środowisku zasadami dotyczącymi oceny nagości (np. kiedy ciało uznawane jest za nagie, w jakich okolicznościach nagość jest dopuszczalna, akceptowalna).

\section{Intymność w ujęciu aksjonormatywnym. Perspektywa prawnicza}

Mówiąc o społecznym wymiarze intymności, trzeba uwzględnić sposób jej ujmowania w systemie aksjonormatywnym - traktowanie jej jako wartości oraz normatywne regulacje dotyczące jej ochrony. Zwraca uwagę fakt, że intymność w zapisach prawnych pojawia się często w powiązaniu z prywatnością, godnością, integralnością fizyczną.

Punktem wyjścia, podstawą dla definiowania praw człowieka, w tym prawa do prywatności i powiązanej z nią intymności, jest godność osobista, traktowana jako przyrodzony, niezbywalny i nienaruszalny atrybut człowieka (Gulla i in. 2019: 131 i nast.). Jej istotą jest autonomia, podmiotowość jednostki. Pojęcia godności i podmiotowości są zresztą często traktowane jako synonimiczne. Mówi się np. o podmiotowym/godnościowym traktowaniu jednostki, co oznacza m.in. przyznanie jej prawa do decydowania o sobie (samostanowienia), szacunek dla jej wyborów i decyzji, wynikający z przypisywania człowiekowi rozumu i wolnej woli (Gulla i in. 2019: 131 i nast.). „W sensie przedmiotowym prawo do godności wyraża się w stworzeniu każdemu takich warunków, by mógł on autonomicznie realizować swą osobowość i nie był obiektem działań innych (zarówno władz, jak i innych osób)" (Gulla i in. 2019: 137). Jak wskazują Gulla, Izydorczyk i Kubiak, poszanowanie godności wiąże się m.in. z ochroną życia i zdrowia człowieka, ochroną integralności fizycznej człowieka (zakazem instrumentalnego traktowania go i naruszania jego cielesności wbrew jego woli) oraz ochroną prywatności (Gulla i in. 2019: 137-138). Prywatność może być, z jednej strony, rozumiana wąsko i odnoszona do zasobu informacji, dotyczących jednostki, udostępnianych przez nią innym, z drugiej strony, w szerszym ujęciu, jest utożsamiana z samostanowieniem człowieka bez ingerencji osób trzecich (Rzucidło 2014: 153). W literaturze przedmiotu wymienia się cztery podstawowe typy definiowania prywatności jako: 1) prawa jednostki do bycia pozostawionym w spokoju; 2) prawa do kontroli informacji na swój temat; 3) kontroli dostępu do własnej osoby; 4) autonomii jednostki (Rzucidło 2014: 153-154).

Będące głównym przedmiotem naszego zainteresowania prawo do intymności jest powiązane z ochroną prywatności i poszanowaniem godności, „respektem wobec sfery osobistej, w której osoba nie jest narażona na dzielenie się z innymi swoimi przeżyciami lub doznaniami o charakterze intymnym" (Gulla i in. 2019: 137-138). Stanowi ono jedno z praw pacjenta („Pacjent ma prawo do poszanowania intymności i godności, w szczególności w czasie udzielania mu świadczeń zdrowotnych") (ustawa z dnia 6 listopada 2008 r. o prawach pacjenta i Rzeczniku 
Praw Pacjenta, Dz.U. 2009 Nr 52 poz. 417, art. 20.1)². Według stanowiska Rzecznika Praw Pacjenta ,przez intymność należy rozumieć zarówno przeżycia wewnętrzne, jak i jego (pacjenta - KDG) fizyczność, których ujawnienie powoduje u przeciętnego człowieka uczucie dyskomfortu lub zażenowania. Naruszenie intymności powoduje uczucie wstydu" (RPP b.r.w.). Odczuwanie tej emocji jest zatem traktowane jako wskaźnik, że prawo do intymności nie jest respektowane (por. też Słowińska 2010: 392). W Fundacji Rodzić po Ludzku, działającej na rzecz ciężarnych i rodzących kobiet oraz matek małych dzieci, podkreśla się, że chodzi tu o indywidualne poczucie wstydu (Prawo do poszanowania intymności i godności b.r.w.). Oznacza to, że określone sytuacje mogą, ale nie muszą wywoływać zawstydzenia, zakłopotania, zażenowania u jednostki. Na podstawie zgłoszeń pacjentów i raportów monitorujących przestrzeganie prawa pacjentów do intymności można jednak wskazać przykłady jego naruszenia, wiążące się z odczuwaniem wstydu (m.in. NIK 2018; Prawo do poszanowania intymności i godności b.r.w.; RPP b.r.w.; Jacek, Ożóg 2012: 268), takie jak:

- konieczność obnażania się do badania i mówienia o sprawach intymnych przed nieznanymi osobami;

- badanie w gabinetach zabiegowych niezabezpieczonych przed wejściem osób nieuprawnionych; wchodzenie osób postronnych do gabinetu lekarskiego w trakcie badania;

- udzielanie świadczeń zdrowotnych w wieloosobowych salach chorych, bez użycia parawanów, przeprowadzanie wywiadu lekarskiego bądź informowanie o stanie zdrowia w obecności innych pacjentów;

- odbieranie pacjentom własnych ubrań i nakaz chodzenia w piżamie po szpitalu;

- brak właściwych warunków sanitarno-higienicznych (toalety i prysznice znajdujące się na korytarzach, zbyt mała ich liczba, niezasłonięte okna i brak zamków w drzwiach), wchodzenie przez personel do łazienek bez pukania i uprzedzenia;

- aroganckie, nieuprzejme, lekceważące traktowanie przez personel medyczny i obsługowy.

Jak pokazują wyniki kontroli przeprowadzonej w polskich szpitalach, problemem jest z jednej strony przestarzałe wyposażenie polskich placówek medycznych, w których nie przewidziano przestrzeni na intymną rozmowę lekarza z pacjentem czy nie zapewniono odpowiednich warunków do przeprowadzenia badania lekarskiego (NIK 2018: 8). Z drugiej strony, poczucie naruszenia intymności

2 Prawo pacjenta do poszanowania intymności i godności osobistej jest definiowane nie tylko w ustawie o prawach pacjenta i Rzeczniku Praw Pacjenta, ale także w ustawie o zawodzie lekarza i lekarza stomatologa (art. 36 ust. 1), a także Kodeksie etyki zawodowej pielęgniarki i położnej Rzeczypospolitej Polskiej (art. 3 pkt a) oraz Kodeksie etyki lekarskiej (art. 12), zobowiązujących osoby wykonujące zawody medyczne do jego respektowania (za: Prawo do poszanowania intymności i godności b.r.w.). 
i godności wywołuje niewłaściwe zachowanie i postępowanie osób wykonujących zawód medyczny, którym wciąż trzeba przypominać o konieczności przestrzegania ogólnie przyjętych form grzecznościowych w kontaktach z pacjentem i jego rodziną oraz traktowania ich życzliwie i z szacunkiem, przeprowadzenia wywiadu i badania z poszanowaniem intymności i godności pacjenta (NIK 2018: 16). Wymaga się od nich podmiotowego podejścia do pacjenta, szanowania jego autonomii i prawa do samostanowienia (Jacek, Ożóg 2012: 268).

\section{Problem intymności w warunkach porodu}

Poród to „bardzo/niesamowicie intymne wydarzenie, najbardziej intymne doświadczenie w życiu kobiety”, czytamy w artykułach na stronach internetowych poświęconych ciąży i macierzyństwu ${ }^{3}$. Ale też pojawiają się takie komunikaty: „Nie spotka cię w życiu nic bardziej odzierającego z intymności. To dotyka niemal każdą kobietę w trakcie porodu" ". Wreszcie mamy do czynienia z deklaracjami: „Poród może być wydarzeniem intymnym”, np. na stronie Fundacji Rodzić po Ludzku. Te przykładowe stwierdzenia pokazują, że rodzenie dziecka jest czymś z natury osobistym, bardzo prywatnym i intymnym ze względu na powiązanie z cielesnością, nagością, fizjologią, ale także intensywnymi przeżyciami emocjonalnymi i psychicznymi. Jednocześnie intymność porodu jest czymś warunkowym, zależącym od tego, czy zewnętrzne okoliczności, osoby towarzyszące na tę intymność pozwolą. Kluczowe znaczenie wydaje się tu mieć medykalizacja porodu ${ }^{5}$, sprawiająca, że naturalny proces narodzin dziecka jest traktowany jako problem medyczny, czynnik ryzyka, wymagający diagnozy, kontroli, nadzoru, zabiegów ze strony ekspertów - profesjonalnych medyków (Nowakowska 2010; Nowakowska 2012; Nowakowska 2014; Oleś-Bińczyk 2011; Mazurek 2014; Pankrac i in. 2015: 298; Nowakowski 2015). Efektem jest

sprowadzenie kobiety rodzącej do biernego obiektu medycznych interwencji, [co prowadzi do] interpretacji ciąży i porodu jako zagrożenia, odebrania rodzącej poczucia sprawstwa oraz bycia kompetentną, a tym samym utraty jej podmiotowości oraz psychicznej satysfakcji, stra-

\footnotetext{
${ }^{3} \mathrm{~Np}$. http://www.parenting.pl, http://www.dziecisawazne.pl (dostęp: 2.08.2021).

${ }^{4} \mathrm{https}$ ://parenting.pl/nie-spotka-cie-w-zyciu-nic-bardziej-odzierajacego-z-intymnosci-todotyka-niemal-kazdej-kobiety-w-trakcie-porodu (dostęp: 2.08.2021).

5 Wskaźnikami medykalizacji porodów są: ,Rutynowe zakładanie wkłucia do żyły obwodowej; Wysoki odsetek porodów szpitalnych; Wysoki odsetek porodów indukowanych; Wysoki odsetek porodów drogami natury z nacięciem krocza; Wysoki odsetek porodów ze stymulowaną akcją skurczową; Asysta lekarza w czasie fizjologicznie przebiegającego porodu; Nadużywanie ciągłego zapisu kardiotokograficznego i wymóg leżenia w trakcie badania; Zbyt częste badanie wewnętrzne; Wysoki odsetek cesarskich cięć; Podawanie kroplówki w porodzie fizjologicznym w celu nawodnienia rodzącej; Niestosowanie/ograniczone stosowanie wertykalnych pozycji w porodzie; Zaciśnięcie pępowiny przed ustaniem tętnienia; Przerwanie dwugodzinnego kontaktu »skóra do skóry«" (F R p L 2017: 22-23).
} 
chu jako motywacji do poddawania się nieuzasadnionym interwencjom, powszechnym przekonaniem, że bezpieczny poród ma miejsce tylko w szpitalu, etc. (Nowakowska 2010: 433).

W skrajnej postaci prowadziło to do przekształcenia porodów w proces ,produkcji dzieci”, jak ujęła to Wochna-Tymińska, opisująca funkcjonowanie szpitali położniczych w PRL, działających jak ,fabryki nowych obywateli” (Wochna-Tymińska 2012: 197). Rodzące były jedynie trybikiem w maszynie, koordynowanej przez personel medyczny, któremu miały się podporządkować. Ich odczucia i potrzeby schodziły na dalszy plan wobec obowiązujących je zasad, rygorów, zaleceń, służących przede wszystkim sprawnemu przebiegowi porodu, prowadzącemu do narodzin zdrowego dziecka. Autorka, na podstawie analizy poradników - ,instrukcji” dla ciężarnych, tak opisuje ówczesne zmedykalizowane podejście do porodów:

[...] urodzenie dziecka jest dla kobiet rodzajem zadania, które mają wykonać. Może być ono procesem niebezpiecznym, ale dzięki precyzyjnie dopracowanym procedurom i wykwalifikowanemu personelowi szpitali położniczych, pod warunkiem bezwzględnego posłuszeństwa, ma szanse zakończyć się pozytywnie. Nie uwzględniano w zasadzie w ogóle faktu, że narodziny dziecka to przede wszystkim wyjątkowe przeżycie natury psychicznej, a kobieta rodząca jest zdrowym, czującym i myślącym człowiekiem, a nie przedmiotem (Wochna-Tymińska 2012: 199).

Obraz placówki położniczej jako fabryki ${ }^{6}$ (Szpitalny poród w PRL byt jak przejście przez taśmociag) przywołuje w wywiadzie także znana położna z ponad pięćdziesięcioletnim stażem, Irena Chołuj (Kisiel 2019). Zwraca ona uwagę na różnicę między określeniami „odbieranie” i „przyjmowanie” porodu. Jak zauważa, w tym pierwszym podkreśla się pierwszoplanową rolę położnej, zarządzającej przebiegiem procesu narodzin dziecka, w którym kobieta pozostaje niejako ubezwłasnowolniona, uprzedmiotowiona, bierna. „Gdy w centrum jest rodząca, a położna za nią podąża, pomaga jej, wspiera - wtedy przyjmuje poród. Niestety, w czasach PRL porody były wyłącznie odbierane" (Kisiel 2019). Podczas pobytu w szpitalu i porodu kobieta była pozbawiona osobistych rzeczy, ubrań i bielizny, a szpitalna koszula nocna, często zniszczona i podarta, nie zakrywała ciała i pozostawiała je obnażone, wystawione na widok publiczny, wywołując uczucie wstydu, zażenowania, nawet upokorzenia (Wochna-Tymińska 2012; Kisiel 2019). Emocje te towarzyszyły także takim obowiązkowym zabiegom jak lewatywa i golenie okolic łonowych, często dokonywanym w obecności innych obcych osób, także nienależących do personelu medycznego. Sam poród odbywał się w wielostanowiskowych salach porodowych, często bez zasłonek czy parawanów (żeby personel medyczny miał kontrolę nad tym, co się dzieje na poszczególnych

${ }^{6}$ Takich określeń używały także same kobiety, opisujące swoje doświadczenie porodu w osobistych relacjach, zbieranych przez Fundację Rodzić po Ludzku, czy listach do miesięcznika „Twoje Dziecko" nadesłanych w ramach konkursu „Złote Bociany dla najlepszych szpitali” ogłoszonego w 1993 roku (Wochna-Tymińska 2012: 197). 
stanowiskach), bez obecności bliskich, wspierających osób, na leżąco, bez możliwości wyboru pozycji rodzenia, bez informacji o swoim stanie i przebiegu akcji porodowej, bez pytania o zgodę na takie zabiegi jak nacinanie krocza, przebijanie pęcherza płodowego czy siłowe ,wypychanie dziecka” (także przy przywiązywaniu nóg rodzącej do podpórek łóżka), z brakiem lub bardzo ograniczonym fizycznym kontaktem z dzieckiem po narodzinach (Wochna-Tymińska 2012: 202-206; Kisiel 2019). Ze wspomnień kobiet wyzierają uczucia upokorzenia, bezsilności, żalu, poczucie krzywdy, uprzedmiotowienia, pozbawienia godności, znieważenia (Wochna-Tymińska 2012: 202-206). Nie ma tu mowy o realizacji prawa do intymności, nie ma mowy o jakiejkolwiek intymności.

Jak zauważa Wochna-Tymińska, zdarzały się placówki, w których rodzące traktowano lepiej, których personel starał się dostosowywać do oczekiwań i potrzeb pacjentek, a także do zaleceń Światowej Organizacji Zdrowia (Wochna-Tymińska 2012: 209). W 1993 roku grupa działaczy społecznych i dziennikarzy $^{7}$ zainspirowanych przez antropolożkę Kitzinger, propagującą przyjazne kobietom zmiany w położnictwie, postanowiła stworzyć ,„»konsumencki« ranking porodówek oparty na listach od kobiet" (Historia akcji b.r.w.). Zebrano 250 porodowych opowieści. Dało to początek akcji „Rodzić po ludzku” z udziałem „Gazety Wyborczej”, rozpropagowanej także przez inne media, która skłoniła tysiące kobiet do podzielenia się swoimi doświadczeniami porodu i doprowadziła do powstania pierwszego przewodnika po szpitalach położniczych w Polsce $(\mathrm{Hi}$ storia akcji b.r.w.). Dalsze działania na rzecz poprawy opieki okołoporodowej, polegające na systematycznym zbieraniu relacji kobiet z przebiegu porodu, ocenie placówek położniczych w ankietach, monitorowaniu ich funkcjonowania prowadzi do dziś założona w wyniku tej akcji w 1996 roku Fundacja Rodzić po Ludzku (25 lat Fundacji b.r.w.). Z jej inicjatywy powstał najpierw Dekalog Rodzenia po Ludzku, następnie (w 2011 roku) Standardy Opieki Okołoporodowej, które w wyniku rozporządzenia Ministra Zdrowia stały się obowiązującym prawem (25 lat Fundacji b.r.w.). Określając pożądany sposób organizacji opieki nad kobietą w ciąży, porodzie i w połogu oraz opieki nad noworodkiem, mają one prowadzić do „humanizacji porodu”, ograniczenia jego zmedykalizowania, uwzględniania potrzeb kobiet, ludzkiego traktowania i przestrzegania ich praw (Nowakow ska 2010; Witek 2018; Kadzikiewicz 2019; Karwowska 2021). Jak czytamy na stronie internetowej Fundacji Rodzić po Ludzku o najnowszych przepisach:

Standard Organizacyjny Opieki Okołoporodowej, czyli Rozporządzenie Ministra Zdrowia z 2018 roku, to dokument, który podkreśla podmiotowość i decyzyjność kobiety podczas porodu. Kobieta ma być w centrum uwagi. Rzetelna informacja ma dawać jej poczucie bezpieczeństwa, a właściwe traktowanie zapewniać poczucie godności i intymności (Dla kobiet b.r.w.).

${ }^{7}$ Osoby związane z Ośrodkiem Edukacji Ekologicznej EKO-OKO oraz miesięcznikiem „Twoje Dziecko" (Historia akcji b.r.w.). 
Mimo stopniowej poprawy sytuacji w polskim położnictwie raporty o opiece okołoporodowej w Polsce i realizacji praw pacjentek w czasie porodu wciąż pokazują częste przypadki naruszeń prawa do intymności i powiązanego z nim prawa do poszanowania godności rodzących kobiet (m.in. NIK 2016; FRpL 2017; FRpL 2018; FnRKiPR 2019). Standardy Opieki Okołoporodowej mające przynieść zmiany nie są w wielu placówkach przestrzegane, co wynika m.in. z tego, że ich wprowadzeniu nie towarzyszyło określenie sposobów kontroli ich realizacji, w związku z tym w części szpitali w ogóle ich nie wdrożono (FRpL 2017: 16; Witek 2018: 196-197). Konieczne jest także edukowanie kobiet w zakresie ich praw i umiejętności ich egzekwowania (co zresztą jest jednym z obszarów działań wspominanej Fundacji Rodzić po Ludzku, prowadzącej także szkolenia personelu medycznego).

Według raportu Najwyższej Izby Kontroli z 2015 roku w części polskich placówek położniczych wciąż problemem jest szpitalna infrastruktura, niezapewniająca poszanowania intymności pacjentek: wieloosobowe pokoje oraz ,wielostanowiskowe sale porodowe", często niewyposażone w toalety (z ogólnodostępnymi łazienkami w korytarzach), w których łóżka są oddzielone jedynie parawanami, a zatem trudno mówić o odosobnionej, intymnej przestrzeni dla rodzących, w których mogłyby się czuć bezpiecznie i swobodnie. Dodatkowo w niektórych szpitalach sale porodowe miały okna wychodzące na korytarz, czyniąc to, co się w nich dzieje, widocznym dla osób postronnych. Kontrola wykazała, że sale porodowe lub gabinety badań były tak urządzone, że „przy otwarciu drzwi osoby postronne mogły zobaczyć pacjentkę w intymnej sytuacji”, a nie było sygnalizacji świetlnej ostrzegającej przed ich wejściem do tych pomieszczeń (lub nie działała) (NIK 2016: 23). Na pytanie w ankiecie o przestrzeganie prawa do zachowania intymności i prywatności co piąta wypowiadająca się rodząca wskazała, że nie było ono respektowane (NIK 2016: 39). Zarejestrowano także wysoki odsetek interwencji medycznych, takich jak przebicie pęcherza płodowego (amniotomia), nacięcie krocza, stymulacja czynności skurczowej (podawanie oksytocyny) oraz cesarskie cięcie. Tego typu zabiegi wykonano średnio u 79\% pacjentek, których dokumentacja medyczna była analizowana (NIK 2016: 12). „Większość ankietowanych pacjentek, które urodziły dziecko drogami natury, stwierdziła, że przed nacięciem krocza nie pytano ich o zgodę na jego wykonanie" (NIK 2016: 23). Takie przypadki wskazują na łamanie prawa do poszanowania godności, podmiotowości i prawa do samostanowienia.

Potwierdzają to raporty Fundacji Rodzić po Ludzku, prezentujące wyniki badań ankietowych, w których zbierano informacje od szpitali i pacjentek (FRpL 2017; FRpL 2018). Mowa w nich nie tylko o nieodpowiednich warunkach i infrastrukturze w części placówek położniczych, o medykalizacji porodów fizjologicznych ${ }^{8}$ i dużym odsetku cięć cesarskich, ale także o nadużywaniu władzy

${ }^{8}$ „Szkodliwe rutyny i przestarzałe procedury wciąż są obecne w większości sal porodowych i oddziałów neonatologicznych. Obowiązkowe niemal zakładanie wenflonu w izbie przyjęć, zbyt 
przez personel medyczny i niewłaściwym traktowaniu rodzących, poniżającym, upokarzającym, naruszającym ich godność (FRpL 2018: 76-81). Analiza odpowiedzi udzielanych przez pacjentki pokazała, że „,W czasie porodu 54,3\% kobiet doświadczyło przemocy lub nadużyć związanych z zachowaniem personelu lub niedopełnieniem wszystkich procedur" (FnRKiPR 2019: 48). Przypadki te obejmowały: „szantażowanie, wyśmiewanie, grożenie, krzyczenie, obrażanie, wypowiadanie niestosownych w odczuciu kobiet komentarzy, szturchanie, rozkładanie na siłę nóg przy parciu, przywiązywanie nóg do łóżka porodowego" oraz takie sytuacje jak: obecność studentów/studentek położnictwa bez zgody badanej, naruszenia prywatności i intymności, nieudzielanie informacji przez personel medyczny bądź formułowanie komunikatów w niezrozumiałym języku, zwracanie się do rodzących w sposób świadczący o braku szacunku, poczucie ankietowanych, że personel gorzej je traktował bądź zmuszał do czegoś (FnRKiPR 2019: 48). Autorzy jednego z raportów przywołują, za Bowser i Hill (2017), pojęcie „przemocowej opieki okołoporodowej podczas porodu" (disrespectful/abusive care during childbirth in facilities) (FRpL 2018: 37). Wśród nadużyć, których doświadczają kobiety w przypadku porodu, wymieniono m.in. przemoc fizyczną i słowną, dyskryminację i stygmatyzowanie (ze względu na takie cechy społeczne jak np. wiek, pochodzenie etniczne, poziom wykształcenia, status ekonomiczny, niepełnosprawność), brak świadomej zgody kobiety na zabiegi i wykonywane czynności, niewłaściwe relacje między personelem i pacjentkami (nieefektywna komunikacja, brak wspierającej opieki, utrata autonomii), brak zapewnionej intymności (FRpL 2018: 38).

\section{Opowieści porodowe jako materiał badawczy}

Jak pokazano w dotychczasowych rozważaniach, chociaż pojęcie intymności funkcjonuje jako hasło w słownikach języka polskiego, pojawia się w przepisach prawnych oraz analizowanych raportach dotyczących jakości opieki okołoporodowej, można odnieść wrażenie, że wymyka się jednoznacznym definicjom, jest trudno uchwytne, mgliste. Wynika to, z jednej strony, z jego zindywidualizowanego, subiektywnego postrzegania i odczuwania. Intuicyjnie każda osoba wie (choć niekoniecznie potrafi to wyrazić słowami), czuje, co jest dla niej intymne, jaki zasięg ma jej sfera intymna i komu pozwala na przekroczenie tej granicy, a także kiedy jej intymność jest naruszana. Kluczowe wydaje się tu odczuwanie emocji

częste wykonywanie badania wewnętrznego i KTG, co jest równoznaczne z przymusem kładzenia rodzącej nieruchomo na plecach, indukcja lub przyspieszanie porodu, podawanie kroplówki nawadniającej zamiast szklanki wody, zmuszanie kobiet do rodzenia na plecach - najbardziej niefizjologicznej i niebezpiecznej dla dziecka i rodzącej pozycji. Po porodzie - przerywanie pierwszego kontaktu między matką a noworodkiem, podawanie dzieciom glukozy zamiast zachęcania matek do karmienia piersią" (FRpL 2017: 15). 
wstydu, zakłopotania, zażenowania, upokorzenia, które, jak już wspomniano, można traktować jako swoisty wskaźnik naruszenia intymności. Z drugiej strony, trudność definiowania intymności wynika z jej powiązania z prywatnością, godnością, autonomią i podmiotowością jednostki. Stąd też zarówno w katalogu praw człowieka i praw pacjenta, jak i w raportach z monitoringu ich przestrzegania pojęcia te są ze sobą zestawiane, łączone, niekiedy traktowane jako bliskoznaczne.

W niniejszym artykule podjęto próbę konkretyzacji pojęcia intymności w warunkach porodu, sięgając po szczególny materiał badawczy - opowieści porodowe. Są to relacje kobiet o doświadczeniu porodu, jego przebiegu z ich perspektywy, towarzyszących mu odczuciach, refleksjach ex post. Wiele takich narracji jest publikowanych w Internecie przede wszystkim na portalach poświęconych porodom, macierzyństwu czy, szerzej, rodzicielstwu? . Jak już wspomniano, od lat porodowe opowieści zbiera Fundacja Rodzić po Ludzku, której misją jest „wzmocnienie i wspieranie kobiet $\mathrm{w}$ otwartym formułowaniu swoich potrzeb i domaganiu się respektowania swoich praw oraz wnoszenie ich doświadczeń do przestrzeni publicznej" (Misja b.r.w.). Na stronie internetowej organizacji w zakładce „Kobiety mówią” oraz „Opowieści porodowe” opublikowano 35 nadesłanych historii i ten właśnie zbiór narracji stanowił materiał badawczy poddany analizie $^{10}$. Są to źródła zastane, niewywołane przez badacza, utrwalone i ogólnie dostępne. Opowieści o doświadczeniu porodu, udostępnione szerszej „publiczności”, są osobistymi dokumentami o charakterze biograficznym, dotyczącymi ważnego momentu w życiu kobiety - narodzin dziecka jako życiowego wydarzenia (Hoerning 1990: 129), punktu zwrotnego (Bu drow ska 2000) czy rytuału przejścia (Jaskulska 2013: 80-81). Można je określić mianem narracji tematycznej (Rokuszewska-Pawełek 2002: 27) czy też historii przypadku, koncentrującej się na określonym procesie w życiu jednostki (Denzin 1990: 68).

Korzystanie z materiałów zastanych wiąże się z takimi ograniczeniami jak brak możliwości ustalenia informacji o autorkach opowieści (wiemy, że były to kobiety, niekiedy poznajemy je z imienia i nazwiska, jedyną dodatkową informacją jest, w przypadku niektórych historii, rok i miejscowość, niekiedy nazwa szpitala, w którym odbył się poród), a także brak wiedzy na temat daty ich nadesłania i udostępnienia oraz ewentualnych skrótów dokonanych przez administratorów strony internetowej. Nie wiemy, dlaczego akurat te historie wybrano i udostępniono spośród setek nadesłanych relacji. Znając cele Fundacji Rodzić po Ludzku oraz charakter jej działalności, możemy przypuszczać, że publikując takie, a nie inne opowieści, starano się przedstawić różnorodność doświadczeń kobiet. Mamy tu relacje z porodów szpitalnych i domowych, naturalnych i przez cesarskie cięcie, mających miejsce zarówno w szpitalach w dużych ośrodkach

${ }^{9}$ M.in. http://www.dobrzeurodzeni.pl, http://www.mamotoja.pl, www.cud-narodzin.pl, http:// www.ladnebebe.pl, http://www.vivatporod.pl (dostęp: 2.08.2021).

${ }^{10} \mathrm{Z}$ analizy wyłączono jedynie relację lekarki, ponieważ nie odnosiła się ona do własnych doświadczeń ciąży i porodu. 
miejskich, jak i mniejszych miejscowościach (np. Racibórz, Wołomin, Szubin) ${ }^{11}$. Sześć opowieści dotyczy pobytu w szpitalu i przeżyć związanych z poronieniem czy urodzeniem martwego dziecka.

Analiza porodowych historii służyła ustaleniu, jakie sytuacje związane z doświadczeniem porodu naruszają sferę intymności kobiety, by następnie zidentyfikować elementy tworzące, warunkujące intymność. Jak rozpoznawano, że w narracji mowa o intymności? Przyjęto, że wskaźnikiem są odczucia narratorki, sposób opowiadania o doświadczeniu, dobór słów, wskazujący na to, że czuła się ona niekomfortowo, nieswojo, nie miała poczucia bezpieczeństwa, co wynikało z wkroczenia innych w jej sferę intymną (nie tylko w sensie dystansu intymnego), była zażenowana, zakłopotana, zawstydzona. Były to także jej wyrazy oburzenia, niezgody, protestu, braku akceptacji dla doświadczanej sytuacji, dotyczącej kontrolowania jej dostępu do własnej osoby, swojego ciała i prywatności, autonomii, godności. Ale nie tylko negatywne doświadczenia autorek opowieści były źródłem informacji o intymności w warunkach porodu. W przypadku pozytywnych historii (w których poród i towarzyszące mu okoliczności były przedstawiane w pozytywnym świetle) pojawienie się kwestii intymności w narracji identyfikowano również poprzez wyrażane przez kobiety odczucia - podkreślanie przez nie, jak komfortowo, bezpiecznie, dobrze się czuły w sytuacji porodu, z otaczającymi je osobami zachowującymi się wobec nich w akceptowany przez nie sposób. Z tych opowieści nie wyłaniał się obraz zawstydzonej, zakłopotanej, zażenowanej, upokorzonej kobiety, mającej poczucie uprzedmiotowienia, przejęcia przez innych kontroli nad jej ciałem, nieliczenia się z jej potrzebami, emocjami. Bohaterkami tych historii były rodzące kontrolujące (w miarę możliwości) przebieg swojego porodu, to, co dzieje się z ich ciałem, stawiające innym granice dostępu do siebie i ich ingerencji, podążające za swoimi odczuciami, chroniące swoją intymność. Różne doświadczenia rodzących - zarówno te negatywne, jak i pozytywne - pozwoliły na poznanie i zrozumienie, czym jest intymność w warunkach porodu, na czym polega jej poszanowanie i naruszenie.

\section{Poród jako (nie)intymne doświadczenie w narracjach rodzących kobiet}

Omawiając doświadczenia intymności bądź jej braku w warunkach porodu, najpierw przyjrzymy się, jakie sytuacje wywoływały u kobiet negatywne emocje i wskazywały na naruszenie ich prywatności, przekroczenie jej granic, „odarcie

${ }^{11} \mathrm{~W}$ zbiorze 34 włączonych do analizy opowieści 25 dotyczyło porodu naturalnego, 4 - porodu przez cesarskie cięcie (przy czym nie były to zabiegi planowane, kobiety chciały i zaczynały rodzić naturalnie, jednak z różnych przyczyn porody kończyły się zabiegiem operacyjnym); 26 relacji przedstawiało poród w szpitalu, 4 - poród domowy. Co do miejsca i daty porodu, jedynie niewielka część historii zawierała takie informacje, co można wytłumaczyć tym, że z punktu widzenia publikującej je organizacji nie były to informacje kluczowe, celem było bowiem pokazanie spektrum doświadczeń porodowych kobiet. 
z godności"12, odebranie podmiotowości. Jak wykazano, godność, podmiotowość, autonomia są ściśle związane z intymnością. Szacunek dla potrzeb, emocji, ciała jednostki, przyznanie jej prawa do kontroli nad dostępem do własnej osoby i decydowania o sobie wiąże się z poszanowaniem tego, co osobiste, prywatne, indywidualne, wewnętrzne - jednym słowem intymne. Zakłada, że każda jednostka ma sobie właściwe, przez siebie ustalone czy raczej odczuwane, granice intymności, których inni bez jej przyzwolenia nie powinni przekraczać.

$\mathrm{Na}$ podstawie analizy porodowych opowieści można wyodrębnić szereg przypadków, które są naruszeniem intymności kobiet. Wstyd, traktowany jako sygnał alarmowy, wskaźnik, że doszło do takiej sytuacji, pojawia się w związku z nagością, niemożnością zakrycia ciała, koniecznością obnażania się przed wieloma osobami:

Ja miałam rozdartą koszulę ledwo kryjącą tyłek, z przodu rozdartą do pępka (OP_14); Kazano mi paradować nago po izbie przyjęć, chodzić z cewnikiem (gdzie chodzili także odwiedzający) po schodach na salę operacyjną (OP_20); Kiedy pojawił się obchód, postanowiono zbadać mi rozwarcie (przy jakichś 10 studentach - zaznaczę, że również nie zapytano mnie o zgodę) (OP_26).

Chociaż, jak wcześniej wspomniano, nagość w relacji z lekarzem ma charakter instrumentalny, roboczy i przymusowy, nie oznacza, że nie wywołuje zawstydzenia pacjenta, szczególnie gdy nie zostają stworzone intymne warunki, by zmniejszyć prawdopodobieństwo wystąpienia tego uczucia, np. poprzez ograniczenie liczby osób, wobec których jednostka musi obnażyć swoje ciało, wystawić je na widok publiczny. Jak zauważa Młynarska-Jurczuk, odwołując się m.in. do teorii seksualnego uprzedmiotowienia (Młynarska-Jurczuk 2016: 366), kobiety są bardziej niż mężczyźni narażone na odczuwanie wstydu w związku ze swoją cielesnością i nagością ze względu na odmienny proces socjalizacji, kształtujący w nich przekonanie o znaczeniu ich ciała i wyglądu dla ich społecznego wizerunku (Młynarska-Jurczuk 2016: 366). W sytuacji obnażenia, odkrycia ciała pojawia się u nich odczucie, że są one przez innych sprowadzane do swojej fizyczności i przez jej pryzmat postrzegane i oceniane jako osoby. Co więcej, wobec istniejących standardów piękna mają świadomość niedoskonałości własnego wyglądu, szczególnie w przypadku zmienionego przez ciążę ciała, znajdującego się dodatkowo w pozostających poza ich kontrolą pozycjach (wymuszonych przez fizyczne odczucia, jak skurcze czy ból kręgosłupa, czy też narzuconych przez personel medyczny). W sytuacji medycznych badań i zabiegów ciężarne i rodzące stają się ciałem, to ich cielesność, a właściwie jej fragmenty - brzuch, narządy płciowe, piersi - są w centrum uwagi, nie one jako osoba, co jest dodatkowo wzmacniane przez ich bezosobowe traktowanie przez personel medyczny. Obrazuje to fragment jednej z opowieści, będącej wyrazem niezgody na taki stan rzeczy:

${ }^{12}$ Określenie jednej z narratorek (OP_1). 
[...] jestem człowiekiem i mam prawo do godnego traktowania. Wiem, że dla lekarza jestem tylko kolejnym przypadkiem, a w swej praktyce codziennie bada i leczy mnóstwo kobiet. Ale dla mnie moje ciało jest tylko moje. Mam w sobie wstyd, skrępowanie i poczucie, że nie jestem w sytuacji komfortowej. Nie pokazuję ciała obcym ludziom - tu musiałam to znieść. Mam prawo źle znosić tę sytuację. Leżąc w kałuży krwi na leżance w trakcie USG, kiedy lekarz niemal siłą rozwierał mi nogi, żeby było wygodniej zobaczyć, co się dzieje, kiedy sonda USG penetrowała moje ciało podczas kolejnych pulsujących chluśnięć krwi, kiedy mnie to koszmarnie bolało... Miałam nie wstawać i poczekać na pielęgniarki, żeby „to” oporządziły. Kiedy leżałam naga w krwi - on uzupełniał papiery. Nie usłyszałam od niego nic ponad: „No to robimy łyżeczkowanie. Kiedy pani jadła?”. [...] Kazał mi się ubrać i umyć ręce do podpisania papierów (OP_1).

Uczucie zawstydzenia, zażenowania, naruszenia prywatności pojawiało się także w opowieściach dotyczących konieczności upubliczniania osobistych informacji o sobie. Kobiety musiały podawać dane osobowe i odpowiadać na pytania, w tym dotyczące stanu zdrowia i takich intymnych kwestii jak miesiączka i wcześniejsze poronienia, w obecności wielu osób, także nienależących do personelu medycznego (salowe, inne pacjentki, odwiedzające je osoby). Miały one poczucie, że muszą kilkakrotnie powtarzać te same informacje, że naraża się je niepotrzebnie na związany z tym stres:

Nie chciałam wszystkiego tłumaczyć w drzwiach, przy ludziach. Ale musiałam (OP_1); Wysłali nas z mężem na salę porodową. Tam czekały na mnie nowe siostry, salowa oparta o zmiotkę. I znowu cała seria tych samych pytań. [...] O godz. 7 była zmiana personelu - i znowu te same pytania, jakby nie mogli przeczytać sobie z karty (OP_14).

W niektórych przypadkach ich dane ujawniane były przez pracowników szpitala, niezadających sobie trudu, by je chronić, nieuznających prawa do prywatności i intymności pacjentek, tak jakby znalezienie się na oddziale położniczym było równoznaczne z zawieszeniem tych praw. Szczegółowo opisała to jedna z narratorek, mająca za sobą doświadczenie poronienia, wyrażająca w swojej opowieści gniew, protest, żal wywołany sposobem zachowania personelu medycznego:

Na zabieg zostałam „wykrzyczana” z korytarza przez pielęgniarki: moje nazwisko słychać było na całym oddziale jak na jakimś jarmarku! „Iść i siąść pod gabinetem zabiegowym na pomarańczowych krzesełkach!" Na miłość boską, czy naprawdę już tak bezosobowo jestem traktowana, że mówią do mnie bezokolicznikami?!?!? [...] Od podstawowego prawa do intymności i poszanowania nie ma odstępstw! [...] wykrzykiwanie przez ordynatora oddziału nazwisk pacjentek z ich dolegliwościami, zwracanie uwagi lekarzom, kim i jak mają się teraz zająć - a to wszystko na korytarzu - jest niedopuszczalne! Nie miał prawa ogłaszać światu, że straciłam dziecko! Tym bardziej, że wśród pielęgniarek i pacjentów były kobiety z mojej miejscowości. Teraz już wiem, że o moim nieszczęściu dowie się więcej osób, z moją rodziną na czele - której nie informowałam o ciąży, bo chciałam to zrobić nieco później, gdy potwierdzi się, że wszystko będzie dobrze (OP_1).

Narracje dotyczące poronienia czy urodzenia martwego dziecka pokazują, że część lekarzy i pielęgniarek nie potrafiła wykazać się taktem, delikatnością, wrażliwością, empatią i uszanować intymności pacjentek i ich bliskich - właściwie 
odczytać ich emocji, właściwie na nie zareagować, nie przekraczać intymnego dystansu (OP_1, OP_7, OP_30). Przejawiało się to w ignorowaniu ich emocji, bagatelizowaniu ich przeżyć (to „nic takiego”, to „się zdarza”), zachowywaniu jak gdyby nigdy nic, braku poszanowania dla indywidualnego sposobu przeżywania utraty ciąży.

Naruszeniem intymności w trakcie porodu jest także odebranie kontroli kobiecie nad własnym ciałem. Nie dość, że musi ona pozwolić na wkroczenie obcych osób w jej intymną sferę i fizyczny kontakt, ich ingerencję w jej ciało i jego procesy, to jeszcze zostaje często niejako ubezwłasnowolniona - pozbawiona nie tylko wpływu na to, co się z jej ciałem dzieje, ale także informacji na temat przebiegu porodu, swojego stanu zdrowia, przeprowadzanych zabiegów medycznych. W opowieściach pojawiały się uwagi o braku pytania kobiet o zgodę na wykonywane czynności i medyczne interwencje, o nieinformowaniu ich o nich i niewyjaśnianiu potrzeby ich przeprowadzenia, nieudzielaniu odpowiedzi na pytania pacjentek czy traktowaniu ich jako problematycznych, roszczeniowych, przeszkadzających, gdy domagały się informacji:

[...] pierwsza ciąża i pierwszy poród były standardowe - szpital, anonimowe położne, aroganccy położnicy, brak szacunku dla moich decyzji i dla mnie (zwracanie się do mnie per ty na przykład, uparte proponowanie zabiegów, na które się bardzo wyraźnie nie zgodziłam, obrażanie się za kwestionowanie poleceń personelu) (OP_4); Nie pozostawia się nam żadnego wyboru, nie pyta o zdanie i zgodę (OP_26); Odniosłam wrażenie, że pacjentki lekarzom na tym oddziale przeszkadzają. Najlepiej, żeby się nie odzywały i niczego nie chciały (OP_1).

$\mathrm{Z}$ drugiej strony, w części narracji przedstawiano komunikację z personelem medycznym jako dwustronną, wzajemną, w której rodząca miała poczucie, że jest postrzegana i dostrzegana jako osoba, a jej intymność i godność są szanowane. Autorki historii opisywały swoje interakcje z lekarzami i położnymi następująco: „poproszono mnie”, ,zaproponowano”, „zapytano”, „tłumaczono”, „pomagano”, „oferowano pomoc”, „udzielano wskazówek”, „doradzano”, „uspokajano”, ,pocieszano". Zaznaczały tym samym, że były traktowane osobowo, z szacunkiem dla ich autonomii, uwzględnieniem ich potrzeb i odczuć, co można wiązać z poszanowaniem ich intymności.

Przejawia się to także w tych wątkach porodowych opowieści, które dotyczą tego, czy kobieta w trakcie porodu mogła decydować o sobie, podążać za swoją intuicją, odczuciami i przekonaniami dotyczącymi tego, jak chce i może zachowywać się jej ciało, co może zmniejszyć jej ból i przynieść ulgę, jak poradzić sobie ze stresem. Te pacjentki, które miały takie doświadczenie porodu, zaznaczały, że mimo trudnego do przewidzenia bólu i ewentualnych komplikacji miały poczucie kontroli nad sytuacją, czuły się podmiotowo, mogły wsłuchiwać się w swoje ciało, poddać naturalnemu biegowi fizjologicznego porodu, co następnie przyczyniło się do wspominania procesu narodzin dziecka jako wyjątkowego wydarzenia, dającego im siłę, wzmacniającego ich kobiecą tożsamość: 
Doznanie siły własnego instynktu, mądrości ciała, prawdziwego cudu narodzin nowego człowieka... Tego chciałam!!! [...] To było dla mnie przeżycie transcendentne. [...] dlatego, że wezbrała we mnie wówczas ta siła, determinacja i kobieca moc, której poszukuję dziś w sobie, kiedy próbuję odnaleźć się w życiu w innych sferach (OP_8); zanurzenie się w sobie [...] bycie w tym doświadczeniu. Poczucie jego siły i siły własnej (OP_34); Poród mojej córki był dla mnie niezwykłym przeżyciem, ekstremalnym i dającym ogromne poczucie siły i sprawstwa (OP_3).

W analizowanych historiach dotyczy to głównie porodów domowych bądź przebiegających w komfortowych warunkach szpitalnych, z udziałem zaprzyjaźnionej położnej, co z reguły wiązało się z dodatkowymi nakładami finansowymi (,Zapewniłam sobie poczucie bezpieczeństwa: spotkaliśmy się ze wspaniałą położną, z którą umówiliśmy się na jej pełną dyspozycyjność dla nas, niezależnie od szpitalnego dyżuru. Oczywiście, trochę kosztowało. Ale był to dla nas priorytet" - OP_8). Wymagało to także przygotowania kobiety, a właściwie pary, bo były to porody rodzinne, polegającego na uczestnictwie w szkole rodzenia, zbieraniu informacji z różnych źródeł, rozmowach z położną i nawiązaniu z nią bliższej relacji, przygotowaniu planu porodu:

W dniu porodu byłyśmy z moją położną już dobrymi znajomymi, między innymi dzięki temu poród nie był dla mnie wydarzeniem medycznym, tylko osobistym i rodzinnym (OP_4); Razem z mężem zapisaliśmy się do szkoły rodzenia, która była prowadzona przy szpitalu. Tam poznaliśmy wspaniałe położne, które [we] wspaniały sposób przedstawiały poród. [...] To dzięki nim byłam przygotowana na wspaniałe przeżycie (OP_32); Wieczorem umówiłam się z położną w szpitalu, żeby podpisać umowę i pogadać o tym, jakie mam oczekiwania wobec niej przy porodzie (OP_9).

Narratorki te potrafiły chronić w ten sposób swoją prywatność i intymność, zapewnić sobie poszanowanie godności i poczucie sprawstwa:

Po prostu wiedziałam, jak chcę i jak nie chcę, i wyegzekwowałam to. Żadnych lewatyw, bo ich nie znoszę, żadnego decydowania za mnie, w jakiej pozycji mam być, wkraczania lekarza wtedy, gdy nie jest potrzebny, żadnego znieczulenia umawianego „na wszelki wypadek” i oksytocyny, żeby było szybciej (OP_8); W domu nikt mi w niczym nie przeszkadzał, nie było stresu, nerwów. [...] to ja byłam u siebie, a położna moim gościem. [...] nikt mi spokoju nie zakłócał, nie wtrącał się, $[\ldots]$ mogliśmy być po prostu tacy, jacy jesteśmy, bez zwracania uwagi na to, że wokół są inni ludzie, kobiety po porodzie, ich goście i mężowie (OP_10).

Inne narracje pokazują, że część kobiet doświadczyła w czasie porodu odebrania im prawa do samostanowienia, rozporządzania własnym ciałem, braku możliwości podążania za sygnałami płynącymi z ich ciała. Narzucano im sposób zachowania i pozycje ciała wbrew ich potrzebom i odczuwanemu bólowi, nie pytano o zgodę na dokonywane zabiegi:

Prosiłam o wstrzymanie się z kroplówką, chciałam zwiększyć swoją aktywność, pochodzić po schodach (do tej pory głównie leżałam pod KTG), ale zbyto moje prośby ironicznym milczeniem. Nikt ze mną nie polemizował. Po prostu personel robił swoje (OP 34); Szkoda tylko, że nie pozwolono mi rodzić w wybranej pozycji, którą ćwiczyłam w ,szkole”. Było tradycyjnie 
na plecach i bardzo niewygodnie. [...] Nie obyło się bez nacięcia krocza i kroplówki z oksytocyną (nie wiem, czy były konieczne) (OP_25); Złościło tylko to, że nic nie jest tak, jak opowiadała położna ze szkoły rodzenia - nie można było wziąć prysznica, pójść do toalety, posiedzieć na piłce czy pochodzić wokół łóżka. Pozwolono mi jedynie stać i patrzeć przez okno. No i nikt nie pytał mnie, w jakiej pozycji chcę rodzić - po prostu leżałam na łóżku z podkurczonymi nogami, na koniec prawie weszła na mnie jedna z lekarek (OP_19).

Z tych wspomnień wyłania się opisywany wcześniej obraz zmedykalizowanego porodu, w którym kobieta ma wykonywać polecenia personelu wiedzącego lepiej i przejmującego pełną kontrolę nad przebiegiem narodzin dziecka. Intymność i jej granice nie istnieją, indywidualne emocje, oczekiwania i potrzeby są ignorowane, traktowane jako nieważne, niewarte uwagi, ciało zostaje zawłaszczone, odebrane kobiecie, stając się przedmiotem medycznych zabiegów, niekonsultowanych z jego ,właścicielką”. Tak jakby rodząca, przekraczając progi szpitala, zawieszała swoją podmiotowość, prawo do swojego ciała, poszanowania godności i intymności i oddawała się do pełnej dyspozycji personelu medycznego, stając się przedmiotem ich działań. Jak trudno kobiecie się z tym pogodzić i jakie może to mieć konsekwencje dla jej samooceny, pokazuje jedna $\mathrm{z}$ historii, zatytułowana „Zmuszona do cesarki”, której autorka chciała rodzić naturalnie, ale w przekonaniu lekarza konieczny był zabieg cesarskiego cięcia:

Czuję się okradziona z pięknych doświadczeń, emocji i siły. Na tym przeklętym stole czułam się jak kupa mięsa, którą należy pokroić i zaszyć. [...] Straciłam zaufanie do siebie, do swojego ciała i do lekarzy. Najtrudniej wybaczyć sobie. Czuję się okaleczona (OP_6).

Poczucie pogwałcenia intymności, godności, autonomii pojawiło się także w innej opowieści:

[...] przyjście na świat pierwszego synka odbyło się przez cesarkę, ale długo po tym miałam poczucie, że coś mi odebrano. Pozwoliłam to sobie odebrać. Jakby przez szpitalne normy i chęć działania personelu nie pozwolono memu ciału działać we własnym tempie. Ja też się w tym zagubiłam i nie stanęłam wystarczająco stanowczo we własnej obronie. Nie miałam wtedy ochoty ani energii na walkę z ludźmi, którzy działali w dobrej wierze, ale wbrew moim odczuciom (OP_34).

Część porodowych opowieści pokazuje, że nawet jeśli poród odbywa się w niekontrolowanych przez kobietę warunkach szpitalnych i ma w dużej mierze zmedykalizowany charakter, to ma ona poczucie poszanowania jej godności i intymności, gdy jest informowana o wykonywanych przez personel medyczny czynnościach, pytana o zgodę na nie, kiedy określone zachowania w czasie porodu są jej proponowane, a nie narzucane, gdy daje jej się prawo wyboru. Rodzące postrzegały to jako wychodzenie naprzeciw ich potrzebom, liczenie się z ich zdaniem i oczekiwaniami, nawet jeśli w niektórych przypadkach, obiektywnie rzecz biorąc, zakres ich autonomii w przebiegu porodu był symboliczny:

Kiedy nastąpił czas porodu, zapytałam panie położne, czy mogłabym rodzić w wodzie. Decyzja moja została przyjęta $z$ entuzjazmem (OP_17); Położna pozwoliła mi na zmianę po- 
zycji, skurcze w pozycji kucznej, miałam udostępnioną piłkę (OP_33); Na sali porodowej miałam dostęp do piłek, ciepłego prysznica i co ważne - mogłam chodzić, a nie cały czas leżeć (OP_22); [...] mogłam korzystać ze sprzętu do ćwiczeń (krzesełka, drabinki, materace), mogłam sama decydować o tym, jaką pozycję przyjmę, czy chcę się napić wody, mąż mógł być cały czas przy mnie i pomagał mi, a położna opiekowała się mną, lekarz kontrolował sytuację (OP_24).

To, że kobieta ma wybór, że może skorzystać z różnych możliwości w zależności od tego, co czuje, czego chce i potrzebuje, można odczytywać jako poszanowanie intymności i autonomii. Tak, wydaje się, było to odbierane przez opowiadające o tym narratorki.

Analizując opowieści kobiet, możemy zauważyć wspominaną wcześniej różnicę między odbieraniem versus przyjmowaniem porodów, sprowadzeniem kobiet do biernych obiektów, podporządkowanych personelowi medycznemu versus traktowaniem ich jako podmiotów, głównych aktorek spektaklu porodu, mających znaczny wpływ na odgrywanie swojej w nim roli. W pierwszym przypadku nie ma mowy o poszanowaniu intymności, w tym drugim to kobieta wyznacza jej granice, decyduje o tym, kto i kiedy może je przekroczyć, a jej poczucie kontroli sytuacji sprawia, że nie pojawiają się negatywne emocje wstydu, zakłopotania, zażenowania, uprzedmiotowienia, upokorzenia. Czuje się ona podmiotem, bohaterką, panią sytuacji, co zostało wyrażone w opowieściach w następujący sposób:

W trakcie samego porodu czułam, że jestem traktowana jak ktoś, kto dokonuje czegoś niezwykłego, a osoby dookoła są po to, aby dawać wsparcie. Profesjonalne, a także, co bardzo ważne, pełne szacunku, koncentracji na mnie i niezwykłego wyczucia moich potrzeb (OP_3); Czułam się kimś wyjątkowym. Przeprosiłam za swoje krzyki i wrzaski, jednak w odpowiedzi usłyszałam, że nie mam za co przepraszać, jeżeli to mi pomagało w rodzeniu, to miałam prawo krzyczeć, wrzeszczeć i wyzywać. Poród to jedyny dzień, w którym kobiecie wszystko wolno! (OP_27).

\section{Zakończenie}

Czym zatem jest intymność w warunkach porodu, czy da się skonkretyzować coś tak subiektywnego, indywidualnego, osobistego, ująć w ogólną definicję? Na podstawie analizy doświadczeń kobiet, opisywanych w porodowych opowieściach, można wskazać elementy, jakie się na intymność w czasie porodu składają. Kluczowa wydaje się kontrola jednostki nad tym, kto ma dostęp do jej ciała, kto może je oglądać i go dotykać, dokonywać na nim zabiegów. Istotne jest poczucie kobiety, że wie, co się dzieje z jej ciałem, nie tylko jest informowana, ale sama o tym decyduje, dając (bądź nie) przyzwolenie na ingerencję innych w jej cielesność. Ta ochrona własnego ciała, ale też swojej prywatności - informacji o sobie, swoich uczuć, granic dostępu innych do własnej osoby - wiąże się z poczuciem podmiotowości, autonomii, sprawstwa. Jak wynika z doświadczeń kobiet, chociaż przebieg porodu fizjologicznego wymyka się kontroli, może wymagać 
medycznych interwencji, w tym cesarskiego cięcia, rodzące mogą być traktowane podmiotowo i czuć się podmiotem. A sam poród może być intymnym wydarzeniem, w którym intymność rodzących jest chroniona i szanowana. Wpływ ma na to m.in. przygotowanie kobiety do porodu, pozwalające jej na kontrolę sytuacji i egzekwowanie swoich praw, traktowanie rodzącej przez personel medyczny jako osoby, która najlepiej orientuje się w swoich potrzebach i emocjach i która ma prawo do informacji, co dzieje się z jej ciałem, i wyrażenia zgody na dokonywane na nim zabiegi. To poszanowanie osobistej godności i intymności wyraża się także w ,ludzkim traktowaniu” pacjentek. Przejawia się ono w tym, że ich uczucia i przekonania, w tym te dotyczące granic intymności i ich przekraczania, są brane pod uwagę; że personel medyczny zwraca się do nich osobowo, z szacunkiem, wykazuje się empatią i stwarza warunki chroniące tę indywidualnie rozumianą, czy raczej odczuwaną, intymność, ograniczając wystąpienie uczuć wstydu, zakłopotania, zażenowania, upokorzenia.

\section{Bibliografia}

25 lat Fundacji Rodzić po Ludzku (b.r.w.), Fundacja Rodzić po Ludzku, Warszawa, https://25lat. rodzicpoludzku.pl/ (dostęp: 1.08.2021).

Banaszak E. (2017), Eksperiencje nagości, Wydawnictwo Naukowe Scholar, Warszawa.

Bieńko M. (2013), Intymne i prywatne praktyki codzienności. Studium socjologiczne, Wydawnictwa Uniwersytetu Warszawskiego, Warszawa, https://doi.org/10.31338/uw.9788323521921

Budrowska B. (2000), Macierzyństwo jako punkt zwrotny w życiu kobiety, Wydawnictwo Funna, Wrocław.

Chajbos K. (2019), Wstyd w życiu Polaków: sposoby rozumienia i doświadczania, role i formy obecności, niepublikowana rozprawa doktorska napisana pod kierunkiem prof. dr. hab. Marka Krajewskiego, Instytut Socjologii, Uniwersytet im. Adama Mickiewicza w Poznaniu.

Czub T., Brzezińska A.I. (2013), Regulacyjna wartość emocji wstydu w procesie ksztaltowania się tożsamości, „Psychologia Rozwojowa”, nr 1(18), s. 27-43.

Danieluk B. (2006), Konceptualizacja poczucia winy $i$ wstydu w ujęciu poznawczym i społecznym, „Annales Universitatis Mariae Curie-Skłodowska. Sectio J, Paedagogia-Psychologia”, vol. 19, s. $71-86$.

Denzin N. (1990), Reinterpretacja metody biograficznej w socjologii: znaczenie a metoda $w$ analizie biograficznej, [w:] J. Włodarek, M. Ziółkowski (red.), Metoda biograficzna w socjologii, Państwowe Wydawnictwo Naukowe, Warszawa-Poznań.

Dla kobiet (b.r.w.), Fundacja Rodzić po Ludzku, Warszawa, https://www.rodzicpoludzku.pl/Dlakobiet (dostęp: 1.08.2021).

Dunaj B. (red.) (1996), Stownik współczesnego języka polskiego, Wilga, Warszawa.

Federacja na Rzecz Kobiet i Planowania Rodziny (FnRKiPR) (2019), Przemoc instytucjonalna $w$ Polsce. O systemowych naruszeniach praw reprodukcyjnych, Federacja na Rzecz Kobiet i Planowania Rodziny, Warszawa.

Fundacja Rodzić po Ludzku (FRpL) (2017), Medykalizacja porodu w Polsce. Raport z monitoringu oddziałów położniczych, Fundacja Rodzić po Ludzku, Warszawa.

Fundacja Rodzić po Ludzku (FRpL) (2018), Opieka okołoporodowa w Polsce w świetle doświadczeń kobiet, Fundacja Rodzić po Ludzku, Warszawa. 
Giddens A. (2004), Socjologia, przeł. A. Szulżycka, Wydawnictwo Naukowe PWN, Warszawa.

Goffman E. (2006a), Porzadek interakcyjny, [w:] Wspótczesne teorie socjologiczne, t. 1, wyb. i oprac. A. Jasińska-Kania, L.M. Nijakowski, J. Szacki, M. Ziółkowski, Wydawnictwo Naukowe Scholar, Warszawa, s. 293-315.

Goffman E. (2006b), Rytuat interakcyjny, przeł. A. Szulżycka, Wydawnictwo Naukowe PWN, Warszawa.

Gulla B., Izydorczyk B., Kubiak R. (2019), Godność i intymność pacjenta. Aspekty psychologiczne i prawne, Uniwersytet Jagielloński, Biblioteka Jagiellońska, Kraków.

Hall E.T. (1978), Ukryty wymiar, przeł. T. Hołówka, Państwowy Instytut Wydawniczy, Warszawa.

Historia akcji (b.r.w.), Fundacja Rodzić po Ludzku, Warszawa, https://www.rodzicpoludzku.pl/ nasze-kampanie/akcja-rodzic-po-ludzku/659-historia-akcji.html (dostęp: 1.08.2021).

Hoerning E.M. (1990), Rola wydarzeń życiowych: doświadczenia i rewitalizacja $w$ perspektywie biograficznej, [w:] J. Włodarek, M. Ziółkowski (red.), Metoda biograficzna w socjologii, Państwowe Wydawnictwo Naukowe, Warszawa-Poznań, s. 127-135.

Jacek A., Ożóg K. (2012), Przestrzeganie praw pacjenta przez personel medyczny, „Hygeia Public Health", nr 47(3), s. 264-271.

Jakubowska H. (2009), Socjologia ciała, Wydawnictwo Uniwersytetu im. Adama Mickiewicza, Poznań.

Jaskulska S. (2013), „Rytuat przejścia” jako kategoria analityczna. Przyczynek do dyskusji nad badaniem rytualnego oblicza rzeczywistości szkolnej, „Studia Edukacyjne”, nr 26, s. 79-97.

Kadzikiewcz J. (2019), Standardy opieki okołoporodowej 2019: Wyzwania i korzyści, https:// www.politykazdrowotna.com/41531,standardy-opieki-okoloporodowej-2019-wyzwania-ikorzysci (dostęp: 1.08.2021).

Karwow ska A. (2021), Wywiad z Joanna Pietrusiewicz, szefowa Fundacji Rodzić po Ludzku, „Wysokie Obcasy", 15 lipca, https://www.wysokieobcasy.pl/wysokie-obcasy/7,100961,27331746, fundacja-rodzic-po-ludzku-dzwonia-do-nas-dyrektorzy-szpitali.html (dostęp: 1.08.2021).

Kisiel A. (2019), Jak wyglądat poród w PRL? Wywiad z położną, Irena Chołuj, https://hellomama. pl/ciaza/porod-w-prl-byl-jak-przejscie-przez-tasmociag/ (dostęp: 5.08.2021).

Konecki K.T. (2014), Socjologia emocji wedtug Thomasa Scheffa, [w:] K.T. Konecki, B. Pawłowska (red.), Emocje w życiu codziennym. Analiza kulturowych, spolecznych i organizacyjnych uwarunkowań ujawniania i kierowania emocjami, Wydawnictwo Uniwersytetu Łódzkiego, Łódź, s. 11-38.

Mazurek E. (2014), Macierzyństwo pod medycznym nadzorem. Wybrane aspekty medykalizacji macierzyństwa, „Kultura - Społeczeństwo - Edukacja”, nr 1(5), s. 75-93.

Misja (b.r.w.), Fundacja Rodzić po Ludzku, Warszawa, https://www.rodzicpoludzku.pl/o-fundacji/ misja.html (dostęp: 1.08.2021).

Młynarska-Jurczuk A. (2016), Wstyd jako emocja ucieleśniona - twarz, ciało i role ptciowe w procesie społecznej konstrukcji wstydu, „Dyskursy Młodych Andragogów”, nr 17, s. 357-369.

Müldner-Nieckowski P. (2003), Wielki stownik frazeologiczny języka polskiego, Świat Książki, Warszawa.

Najwyższa Izba Kontroli (NIK) (2016), Opieka okołoporodowa na oddziałach położniczych. Informacja o wynikach kontroli, Najwyższa Izba Kontroli, Warszawa.

Najwyższa Izba Kontroli (NIK) (2018), Ochrona intymności i godności pacjentów w szpitalach. Informacja o wynikach kontroli, Najwyższa Izba Kontroli, Warszawa.

Nowakow ska L. (2010), W stronę humanizacji porodu, „Zdrowie publiczne”, nr 120(4), s. 431-435.

Nowakowska L. (2012), Humanizacja ciaży $i$ porodu. Perspektywa socjologii medycyny, [w:] M. Synowiec-Piłat, A. Olchowska-Kotala (red.), Socjologia i psychologia dla pacjenta. Wybrane zagadnienia, Wydawnictwo Adam Marszałek, Toruń, s. 245-255. 
Nowakowska L. (2014), Refleksje nad ciąża i porodem. Perspektywa krytycznej analizy dyskursu, „Kultura - Społeczeństwo - Edukacja”, nr 1(5), s. 9-24, https://doi.org/10.14746/ kse.2014.5.1.01

Nowakowski M. (2015), Medykalizacja i demedykalizacja. Zdrowie i choroba w czasach kapitalizmu zdezorganizowanego, Wydawnictwo Uniwersytetu Marii Curie-Skłodowskiej, Lublin.

Oleś-Binczyk Z. (2011), Medykalizacja ciąży i porodu w Polsce, [w:] A. Palęcka, H. Szczodry, M. Warat (red.), Kobiety w społeczeństwie polskim, Wydawnictwo Uniwersytetu Jagiellońskiego, Kraków, s. 43-63.

Pankrac Z., Filipska-Kozak E., Hofman A., Kiełbratowska B. (2015), Realizacja praw pacjenta podczas porodu w szpitalu, „Zdrowie i Dobrostan”, nr 2, s. 297-308.

Polińska A. (2020), Nagość. Studium prawne ze szczególna perspektywa polskiego prawa karnego, niepublikowana rozprawa doktorska napisana pod kierunkiem dr. hab. Radosława Krajewskiego, Wydział Prawa i Administracji, Uniwersytet Warmińsko-Mazurski w Olsztynie.

Prawo do poszanowania intymności i godności (b.r.w.), Fundacja Rodzić po Ludzku, Warszawa, https://www.rodzicpoludzku.pl/prawa-pacjenta/prawo-do-poszanowania-intymnosci-igodnosci/prawo-do-poszanowania-intymnosci-i-godnosci.html (dostęp: 1.08.2021).

Rokuszewska-Pawełek A. (2002), Chaos i przymus. Trajektorie wojenne Polaków - analiza biograficzna, Wydawnictwo Uniwersytetu Łódzkiego, Łódź.

Rzecznik Praw Pacjenta (RPP) (b.r.w.), Przykłady naruszeń praw pacjenta do poszanowania intymności i godności, https://www.gov.pl/web/rpp/przyklady-naruszen-prawa-pacjenta-doposzanowania-intymnosci-i-godnosci (dostęp: 2.08.2021).

Rzepa T., Żaba R., Jakubowicz O. (2013), Rozumienie wstydu oraz ocena jego źródet przez osoby zdrowe i pacjentów ze wstydliwymi chorobami, „Opuscula Sociologica”, nr 4(6), s. 51-61.

Rzucidło J. (2014), Prawo do prywatności i ochrona danych osobowych, [w:] M. Jabłoński (red.), Realizacja i ochrona konstytucyjnych wolności i praw jednostki w polskim porządku prawnym, Wydział Prawa, Administracji i Ekonomii Uniwersytetu Wrocławskiego, Wrocław, s. $153-175$.

Scheff T.J. (2011), Shame in Self and Society, „Symbolic Interaction”, t. 26(2), s. 239-262, https:// doi.org/10.1525/si.2003.26.2.239

Słowińska A. (2010), Prawo pacjenta do intymności podczas udzielania świadczeń zdrowotnych, „Forum Medycyny Rodzinnej”, t. 4(5), s. 392-393.

Sut P. (2019), Relacje prawo - intymność jako przedmiot prawniczej refleksji, Wydawnictwo Uniwersytetu Gdańskiego, Gdańsk.

Szymczak M. (red.) (1988), Słownik języka polskiego, t. 1, Państwowe Wydawnictwo Naukowe, Warszawa.

Witek Z. (2018), Regulacje prawne w zakresie opieki okołoporodowej w Polsce w kontekście projektu nowego standardu organizacyjnego, „Studia Prawa Publicznego”, nr 3(23), s. 179-210.

Wochna-Tymińska A. (2012), Zakład produkcji dzieci, [w:] M. Kula (red.), Kłopoty z seksem w PRL. Rodzenie nie catkiem po ludzku, aborcja, choroby, odmienności, Wydawnictwa Uniwersytetu Warszawskiego, Warszawa, s. 187-239.

\section{Akty prawne}

Ustawa z dnia 6 listopada 2008 r. o prawach pacjenta i Rzeczniku Praw Pacjenta (Dz.U. 2009 Nr 52 poz. 417), http://isap.sejm.gov.pl/isap.nsf/download.xsp/WDU20090520417/U/D20090417Lj. pdf (dostęp: 2.08.2021). 


\title{
THE MEANING OF THE NOTION OF INTIMACY AND THE RIGHT TO RESPECT FOR IT IN THE LIGHT OF THE EXPERIENCES OF WOMEN GIVING BIRTH
}

\begin{abstract}
The subject of interest in this article is intimacy in childbirth - how it is perceived by parturients, what determines that the birth of a child is an intimate event for them, what is a violation of their intimacy. A qualitative study was carried out, based on the analysis of birthing stories collected and made public by the Childbirth with Dignity Foundation. The starting point for the analysis was to determine how the concept of intimacy is understood in Polish language, what it means in the processes of social interaction and communication, what emotions are associated with the violation of intimacy, as well as how it is defined and protected in Polish legislation, including laws defining patient rights. The results of the research on the realization of the right to intimacy, respect for dignity and autonomy in Polish in obstetric hospitals are also presented. Analyzing the narratives of women in which they shared their experiences and reflections on childbirth and stays in hospital due to miscarriage, it was assumed that the indicator of violation/respect for their intimacy are their feelings, emotions expressed in the stories, and the way they talked about the experience. The analysis of birth stories allowed to establish that intimacy during childbirth is associated with a woman's sense of control over others' access to her body, her knowledge and consent regarding activities and medical interventions that interfere with her corporeality and the process of childbirth. It is also crucial that the medical staff respects the emotions, needs and expectations of the patient, treating her with respect, as a person, a subject, a leading actor in the birth process. Consideration and protection of the limits of individual intimacy is associated with the recognition of their autonomy and empowerment, and respect for their personal dignity.
\end{abstract}

Keywords: childbirth, birth stories, intimacy, dignity, autonomy, subjectivity, shame. 